\title{
Original Article \\ Extraction of Rice Bran Oil from Rice Bran by Supercritical Carbon Dioxide
}

\author{
Nguyen Van Khanh ${ }^{1, *}$, Nguyen Thanh Hai ${ }^{1}$, Nguyen Thi Huyen ${ }^{1}$, \\ Dao Anh Hoang ${ }^{2}$, Tran Quoc Thinh ${ }^{3}$ \\ ${ }^{1}$ VNU University of Medicine and Pharmacy, 144 Xuan Thuy, Cau Giay, Hanoi, Vietnam \\ ${ }^{2}$ National Institute of Medicinal Materials, 3B Quang Trung, Hoan Kiem, Hanoi, Vietnam \\ ${ }^{3}$ Nghe An Traditional Medicine Hospital, 1 Tue Tinh, Vinh, Nghe An, Vietnam \\ Received 16 December 2020 \\ Revised 19 February 2021; Accepted 02 April 2021
}

\begin{abstract}
Rice bran is an important source of nutrients that have many good bioactive compounds. This study examined the extraction of bran rice oil using supercritical carbon dioxide. Free fatty acids contained in bran rice were stabilized at $5.25 \%$ for 8 months by fluid bed dryer equipment. Supercritical carbon dioxide extraction of rice bran oil at pressure of $400 \mathrm{bar}$, temperature of $60{ }^{\circ} \mathrm{C}$, $\mathrm{CO}_{2}$ flow rate of $20 \mathrm{~g} / \mathrm{min}$ for 120 minutes yielded $14.84 \%$ oil. The concentration of $\gamma$-oryzanol in rice bran oil extracted by supercritical carbon dioxide $(0.50 \%)$ was higher than in rice bran oil derived from hexane Soxhlet extraction $(0.42 \%)$. The effect of pressure and temperature on extraction yield and the concentration of $\gamma$-oryzanol contained in rice bran oil was observed.
\end{abstract}

Keywords: rice bran, rice bran oil, $\gamma$-oryzanol, free fatty acid, supercritical carbon dioxide.

\footnotetext{
* Corresponding author.

E-mail address: khanha7k64dkh@gmail.com

https://doi.org/10.25073/2588-1094/vnuees.4286
} 


\title{
Nghiên cứu chiết xuất dầu cám gạo bằng dung môi $\mathrm{CO}_{2}$ siêu tới hạn
}

\author{
Nguyễn Văn Khanh ${ }^{1, *}$, Nguyễn Thanh Hải ${ }^{1}$, Nguyễn Thị Huyền ${ }^{1}$, \\ Đào Anh Hoàng ${ }^{2}$, Trần Quốc Thịnh ${ }^{3}$ \\ ${ }^{1}$ Truoòng Đại học Y Dượ, Đại học Quốc gia Hà Nội, 144 Xuân Thủy, Cầu Giấy, Hà Nội, Việt Nam \\ ${ }^{2}$ Viện Duợc liệu, $3 B$ Quang Trung, Hoàn Kiếm, Hà Nội, Việt Nam \\ ${ }^{3}$ Bệnh viện Y học Cổ truyền Nghệ An, 1 Tuệ Tĩnh, Thành phố Vinh, Nghệ An, Việt Nam \\ Nhận ngày 16 tháng 12 năm 2020 \\ Chỉnh sửa ngày 19 tháng 02 năm 2020; Chấp nhận đăng ngày 02 tháng 4 năm 2021
}

\begin{abstract}
Tóm tắt: Cám gạo là một nguồn dinh dưỡng quan trọng chứa nhiều thành phần có hoạt tính sinh học tốt. Mục đích của nghiên cứu là chiết xuất dầu cám gạo bằng phương pháp sử dụng môi $\mathrm{CO}_{2}$ siêu tới hạn. Hàm lượng acid béo tự do trong cám gạo đã được ổn định trong 8 tháng bằng phương pháp sấy tầng sôi $(5,25 \%)$. Chiết xuất dầu cám bằng dung môi $\mathrm{CO}_{2}$ siêu tới hạn ở áp suất 400 bar, nhiệt độ $60^{\circ} \mathrm{C}$, tốc độ dòng $20 \mathrm{~g} /$ phút, thời gian chiết 120 phút thu được hiệu suất $14,84 \%$. Nồng độ của $\gamma$-oryzanol trong dầu cám chiết xuất bằng dung môi $\mathrm{CO}_{2}$ siêu tới hạn là $0,50 \%$, cao hơn so với phương pháp chiết Soxhlet với dung môi n-hexan $(0,42 \%)$. Nghiên cứu cũng đã chỉ ra sự ảnh hưởng của áp suất và nhiệt độ lên hiệu suất chiết xuất và hàm lượng $\gamma$-oryzanol trong dầu cám gạo.
\end{abstract}

Tù khóa: Cám gạo, dầu cám gạo, $\gamma$-oryzanol, acid béo tự do, $\mathrm{CO}_{2}$ siêu tới hạn.

\section{Mở đầu}

Gạo là một loại ngũ cốc quan trọng, là lương thực chủ yếu của hơn một nửa dân số thế giới [1]. Năm 2010, sản lượng lúa gạo trên thế giới đạt gần 700 triệu tấn [2]. Việt Nam là một nước có nền nông nghiệp lâu đời, cây lúa đã trở thành cây lương thực chủ yếu có ý nghĩa quan trọng trong đời sống và nền kinh tế nông nghiệp.

Quá trình sản xuất gạo tạo ra cám gạo, chiếm $10 \%$ khối lượng hạt thóc [3, 4], được coi là phụ phẩm nông nghiệp, được dùng làm thức ăn chăn nuôi hoặc xuất khẩu dưới dạng nguyên liệu thô. Cám gạo chứa $12-16 \%$ protein, $7-11 \%$ chất xơ, $34-52 \%$ carbohydrat, $7-10 \%$ tro và $15-20 \%$ lipid [5]. Dầu cám gạo được sử dụng làm dầu ăn phổ biến trong rất nhiều quốc gia trên thế giới do có điểm khói cao và hương thơm dễ chịu [6]. Các thành phần trong dầu cám gạo, đặc biệt $\gamma$-oryzanol đã được chứng minh có một số tác dụng tốt như giảm cholesterol, hạ lipid máu [7], hạ glucose máu ở bệnh nhân tiểu đường type 2 , tăng cường chức năng dạ dày, gan, ức chế tế bào ung thư đại tràng, dạ dày, chống lão hóa, chống oxy hóa,... [8, 9].

Hiện nay, công nghệ chiết sử dụng dung môi $\mathrm{CO}_{2}$ siêu tới hạn để sản xuất hoạt chất và hương liệu có nguồn gốc từ thiên nhiên, là một kĩ thuật đang được phát triển cạnh tranh với các kỹ thuật truyền thống do có ưu thế vượt trội, tạo các sản phẩm có độ tinh khiết cao, giảm thiểu ô nhiễm môi trường và không để lại dư lượng hóa chất có hại cho sức khỏe con người [10].

\footnotetext{
* Tác giả liên hệ.

Địa chỉ email: khanha7k64dkh@gmail.com

https://doi.org/10.25073/2588-1094/vnuees.4286
} 
Do vậy, để góp phần nâng cao giá trị của lúa gạo, tạo cơ sở cho sản xuất các chế phẩm có tính ứng dụng cao trong dược phẩm, hóa mỹ phẩm và thực phẩm, chúng tôi thực hiện nghiên cứu chiết xuất các thành phần có hoạt tính từ cám gạo bằng phương pháp dùng dung môi $\mathrm{CO}_{2}$ siêu tới hạn và đánh giá hàm lượng $\gamma$-oryzanol trong dầu cám gạo chiết được.

\section{Nguyên liệu và phương pháp}

\subsection{Nguyên liệu}

Mẫu cám gạo của giống lúa T161 trồng tại Nhân Hòa, Mỹ Hào, Hưng Yên thu tại cơ sở xay xát ở địa phương; $\gamma$-oryzanol chuẩn (CAS: 11042-64-1, Tokyo chemical industry, Nhật Bản), acid oxalic, n-heptan, n-hexan, ethanol, diethyl ether, kali hydroxyd, phenolphthalein (Trung Quốc).

Tá dược và hóa chất đều đạt tiêu chuẩn dược dụng hoặc tinh khiết phân tích.

\subsection{Thiết bi}

Máy đo quang UV-2600 Shimadzu (Nhật Bản), cân kỹ thuật Shimadzu (Nhật Bản), cân phân tích AY 129 Shimadzu (Nhật Bản), hệ thống chiết xuất $\mathrm{CO}_{2}$ siêu tới hạn SFE500 hãng Waters (Mỹ), bộ chiết Soxhlet (Trung Quốc), máy cất quay Rotavapor R-210 Buchi (Thụy sỹ), bếp điện WHM12012 Daihan (Hàn Quốc), máy sấy tầng sôi FG-5 (Trung Quốc), bếp cách thủy WB 5 (Israel), tủ sấy tĩnh UNB 500 Memmert (Đức).

\subsection{Phuoong pháp nghiên cúu}

Xử lý độ ổn định nguyên liệu cám gạo: trong quy trình xay xát gạo, cám xoa là phần cám thu được khi đánh bóng hạt gạo sau khi xát lần thứ nhất, cám có màu trắng ngà, bao gồm có một phần gạo, mầm hạt gạo, lớp cám bên trong được rây qua cỡ mắt rây $180 \mu \mathrm{m}$ (mẫu cám $\mathrm{C} 1$ ). Mẫu cám C1 được sấy tầng sôi ở nhiệt độ $140^{\circ} \mathrm{C}$ trong 10 phút, sau đó sấy $90^{\circ} \mathrm{C}$ đến khô trong thời gian 60 phút. Mẫu cám gạo sau khi được xử lý với nhiệt (mẫu cám $\mathrm{C} 2$ ) được đóng vào túi $\mathrm{PE}$ kín, bảo quản ở nhiệt độ phòng và được đánh giá sự thay đổi về hàm lượng acid béo tự do trong 8 tháng kể từ thời điểm xay xát.

Chiết xuất dầu cám gạo bằng dung môi $\mathrm{CO}_{2}$ siêu tới hạn: tham khảo một số các nghiên cứu trước $[11,12]$, tiến hành khảo sát chiết 50 gam mẫu cám $\mathrm{C} 2$ bằng dung môi $\mathrm{CO}_{2}$ siêu tới hạn ở các điều kiện như sau: áp suất (350-450 bar), nhiệt độ $\left(40-80{ }^{\circ} \mathrm{C}\right)$, tốc độ dòng $\mathrm{CO}_{2}(20-30$ $\mathrm{g} /$ phút), thời gian chiết xuất (30-180 phút). Dầu cám gạo chiết xuất được bảo quản trong tủ lạnh ở $4{ }^{\circ} \mathrm{C}$.

Chiết xuất dầu cám gạo bằng phương pháp Soxhlet: 10 gam mẫu cám $\mathrm{C} 2$ được chiết xuất với $200 \mathrm{ml} \mathrm{n}$-hexan trên bộ chiết Soxhlet trong thời gian 8 giờ. Dịch chiết sau đó được loại bỏ dung môi $\mathrm{n}$-hexan bằng máy cô quay dưới áp suất giảm thu được dầu cám gạo, sau đó được sấy ở $60{ }^{\circ} \mathrm{C}$ tới khối lượng không đổi.

Xác định hiệu suất chiết dầu cám gạo:

Hiệu suất chiết dầu cám gạo được tính theo công thức sau [11, 12]:

Hiệu suất chiết(\%) $=\frac{\text { Khối lượng dầu cám gạo }}{\text { Khối lượng cám gạo }} \times 100$

Trong đó: khối lượng dầu cám gạo là khối lượng dầu cám gạo chiết xuất được (g);

Khối lượng cám gạo là khối lượng cám gạo dùng để chiết xuất $(\mathrm{g})$.

Xác định độ acid (hàm lượng acid béo tự do) trong cám gạo: tiến hành đánh giá hàm lượng acid béo tự do trong cám gạo bằng phương pháp chuẩn độ theo Tiêu chuẩn Việt Nam (TCVN 6127:2007).

Chuẩn bị: dung dịch kali hydroxyd (đã được chuẩn độ bằng dung dịch acid oxalic chuẩn $0,01 \mathrm{~N})$. Pha hỗn hợp dung môi ethanol $96 \%$ và diethyl ether theo tỉ lệ thể tích 1:1. Trung hòa hỗn hợp dung môi bằng dung dịch kali hydroxyd.

Tiến hành: cân chính xác khoảng $10 \mathrm{~g}$ mẫu cám gạo cho vào bình nón $250 \mathrm{ml}$. Thêm $50 \mathrm{ml}$ hỗn hợp dung môi đã trung hòa và hòa tan phần mẫu thử bằng cách làm nóng nhẹ. Thêm khoảng $0,5 \mathrm{ml}$ chất chỉ thị phenolphtalein, chuẩn độ bằng dung dịch kali hydroxyd. Việc chuẩn độ được coi là kết thúc khi thêm một giọt kiềm làm đổi màu dung dịch sang hồng nhạt (ổn định trong ít nhất 15 giây). 
Tính toán: chỉ số acid (hàm lượng acid béo tự do) trong cám gạo được tính theo công thức sau:

Hàm lượng acid béo tự do $(\%)=\frac{0,5 \text { x } 56,1 \text { x c x V }}{\mathrm{m}}$

Trong đó:

c là nồng độ của dung dịch chuẩn kali hydroxyd đã sử dụng, tính bằng mol trên lít (mol/l);

$\mathrm{V}$ là thể tích của dung dịch chuẩn kali hydroxyd đã sử dụng, tính bằng mililit $(\mathrm{ml})$;

$\mathrm{m}$ là khối lượng phần mẫu thử, tính bằng gam $(\mathrm{g})$.

Định lượng $\gamma$-oryzanol trong dầu cám gạo bằng phương pháp đo quang: cân chính xác một lượng dầu cám gạo hòa tan trong một lượng n-heptan thích hợp (nồng độ $\gamma$-oryzanol nằm trong khoảng từ 4-16 $\mu \mathrm{g} / \mathrm{ml})$, lọc bằng giấy lọc thu được dịch lọc, đo độ hấp thụ quang tại bước sóng cực đại $\lambda=315 \mathrm{~nm}$, với mẫu trắng là dung dịch n-heptan.

\section{Kết quả nghiên cứu và bàn luận}

\subsection{Khảo sát độ ổn định của cám gạo}

Tiến hành đánh giá chất lượng cám gạo bằng cách theo dõi hàm lượng acid béo tự do trong thời gian 8 tháng của mẫu cám $\mathrm{C} 2$ sau khi được xử lý với nhiệt so với mẫu cám $\mathrm{C} 1$. Kết quả thu được như trong Bảng 1.

Bảng 1. Hàm lượng acid béo tự do trong mẫu cám $\mathrm{C} 1$ và $\mathrm{C} 2$ trong thời gian 8 tháng

\begin{tabular}{|l|l|l|l|l|l|}
\hline \multirow{2}{*}{ Mẫu } & \multicolumn{4}{|l|}{ Hàm lượng acid béo tự do sau thời gian bảo quản (\%) } \\
\cline { 2 - 6 } & 0 tháng & 1 tháng & 2 tháng & 4 tháng & 8 tháng \\
\hline Mẫu cám C1 & 1,25 & 9,45 & 11,91 & 14,42 & 18,85 \\
\hline Mẫu cám C2 & 1,25 & 1,85 & 2,30 & 3,60 & 5,25 \\
\hline
\end{tabular}

Kết quả cho thấy ở mẫu cám C1 không được xử lý với nhiệt thì hàm lượng acid béo tự do tăng rất nhanh ngay sau một tháng $(9,45 \%)$ và sau 8 tháng hàm lượng acid béo tự do tăng gấp khoảng 15 lần $(18,85 \%)$. Nguyên nhân là do tác động của enzym lipase xúc tác cho phản ứng thủy phân trigycerid tạo thành glycerin và acid béo tương ứng dẫn tới tăng hàm lượng acid béo tự do trong cám gạo [13]. Vì thế nếu cám gạo trong 24 giờ đầu sau khi xay xát không được xử lý thì lượng acid béo tự do tăng lên rất nhanh gây biến đổi chất lượng, làm mất giá trị của cám gạo [14]. Mẫu cám $\mathrm{C} 2$ là mẫu cám $\mathrm{C} 1$ được xử lý với nhiệt thì sau 8 tháng bảo quản hàm lượng acid béo tự do tăng không nhiều $(5,25 \%)$. Kết quả này cũng phù hợp như theo nghiên cứu năm 2004 của G. S. Chauhan và cộng sự [15], sau 60 ngày bảo quản thì hàm lượng acid béo tự do trong mẫu mẫu cám gạo xử lý với nhiệt nóng tăng lên không nhiều từ $3,66 \%$ lên $9,15 \%$, còn mẫu xử lý bằng phương pháp đùn nóng hầu như không thay đồi trong suốt quá trình bảo quản $(3,85 \%$ so với 4,1\%). Tương tự năm 2004, Lakkakula và cộng sự [16] đã ổn định chất lượng cám gạo bằng nhiệt sử dụng dòng điện, sau 6 tuần bảo quản thì hàm lượng acid tự do tăng nhẹ (5,54\%). Theo một số nghiên cứu trước thì hàm lượng acid béo tự do trong dầu cám gạo nên dưới $5 \%$ và không được vượt quá $15 \%[17,18]$.

Như vậy phương pháp sấy tầng sôi đã làm bất hoạt enzyme lipase trong cám gạo, ổn định được chất lượng dầu cám gạo. Cám gạo sau xử lý với nhiệt có thể bảo quản được trong một thời gian dài mà không bị phân hủy, có mùi ôi khét.

Mẫu cám $\mathrm{C} 2$ được sử dụng cho chiết xuất dầu cám gạo bằng dung môi $\mathrm{CO}_{2}$ siêu tới hạn trong các nghiên cứu tiếp theo.

3.2. Khảo sát các điều kiện chiết xuất dầu cám gạo bằng phương pháp sư dụng dung môi $\mathrm{CO}_{2}$ siêu tới hạn

Khảo sát khoảng thời gian chiết xuất: tiến hành chiết dầu cám gạo với các thông số quy trình như sau: khối lượng mẫu cám $\mathrm{C} 2$ là $50 \mathrm{~g}$, nhiệt độ $40^{\circ} \mathrm{C}$, áp suất 350 bar, tốc độ dòng $\mathrm{CO}_{2}$ $25 \mathrm{~g} /$ phút, thời gian chiết 30-180 phút. Dầu cám 
gạo sau khi chiết được đánh giá hàm lượng $\gamma$-oryzanol. Kết quả như trong Bảng 2.

Bảng 2. Hiệu suất chiết dầu cám gạo và hàm lượng $\gamma$-oryzanol khi thay đổi thời gian chiết

\begin{tabular}{|l|l|l|}
\hline $\begin{array}{l}\text { Thời } \\
\text { gian } \\
\text { (phút) }\end{array}$ & $\begin{array}{l}\text { Hiệu suất chiết } \\
\text { dâu cám gạo }(\%)\end{array}$ & $\begin{array}{l}\text { Hàm lượng } \\
\gamma \text {-oryzanol }(\%)\end{array}$ \\
\hline 30 & 6,82 & 0,27 \\
\hline 60 & 11,08 & 0,28 \\
\hline 120 & 14,48 & 0,27 \\
\hline 180 & 14,52 & 0,27 \\
\hline
\end{tabular}

Kết quả cho thấy khi tăng thời gian chiết thì hiệu suất chiết dầu cám gạo tăng lên còn hàm lượng $\gamma$-oryzanol trong dầu cám thì hầu như không thay đổi (khoảng 0,27-0,28\%). Tốc độ chiết dầu cám gạo giảm dần theo thời gian, lượng dầu chiết được ở thời điểm 120 phút và 180 phút tương đương nhau lần lượt là $14,48 \%$ và $14,52 \%$. Kết quả này cho thấy sau 120 phút chiết xuất thì lượng dầu trong cám gần như đã được chiết kiệt. Nguyên nhân là do càng về sau thì lượng dầu trong cám càng ít đi, do vậy làm giảm tốc độ chiết dầu cám gạo.

Như vậy thời gian chiết chủ yếu ảnh hưởng tới hiệu suất chiết xuất, hầu như không ảnh hưởng tới hàm lượng $\gamma$-oryzanol trong dầu cám gạo. Sau 120 phút thì dầu cám gạo đã được chiết gần như hoàn toàn, do vậy thời gian chiết là 120 phút được sử dụng trong các nghiên cứu tiếp theo.

Bảng 3. Hiệu suất chiết dầu cám gạo và hàm lượng $\gamma$-oryzanol khi thay đổi áp suất

\begin{tabular}{|l|l|l|}
\hline $\begin{array}{l}\text { Áp suất } \\
\text { (bar) }\end{array}$ & $\begin{array}{l}\text { Hiệu suất chiết } \\
\text { dầu cám gạo }(\%)\end{array}$ & $\begin{array}{l}\text { Hàm lượng } \\
\gamma \text {-oryzanol }(\%)\end{array}$ \\
\hline 350 & 14,88 & 0,27 \\
\hline 400 & 15,50 & 0,31 \\
\hline 450 & 15,06 & 0,28 \\
\hline
\end{tabular}

Khảo sát sự ảnh hưởng của áp suất chiết: tiến hành chiết dầu cám gạo với các thông số quy trình như sau: khối lượng mẫu cám $\mathrm{C} 2$ là $50 \mathrm{~g}$, nhiệt độ chiết $40^{\circ} \mathrm{C}$, áp suất chiết 350-450 bar, tốc độ dòng $\mathrm{CO}_{2} 25 \mathrm{~g} /$ phút, thời gian chiết 120 phút. Kết quả được trình bày trong Bảng 3 .
Kết quả cho thấy khi thay đổi áp suất chiết thì hiệu suất chiết dầu cám gạo thu được thay đổi không đáng kể (hiệu suất chiết dầu cám gạo ở $350,400,450$ bar lần lượt là $14,88 \% ; 15,50 \%$; $15,06 \%)$. Tuy nhiên có sự khác biệt về chất lượng dầu cám (hàm lượng $\gamma$-oryzanol), trong đó ở áp suất 400 bar thu được hàm lượng $\gamma$-oryzanol cao nhất $(0,31 \%)$, như vậy ở áp suất 400 bar thì $\gamma$-oryzanol hòa tan tốt hơn trong dung môi $\mathrm{CO}_{2}$ siêu tới hạn so với ở các áp suất khác.

Khi giữ nhiệt độ ở $40{ }^{\circ} \mathrm{C}$, tăng dần áp suất chiết thì tỷ trọng của $\mathrm{CO}_{2}$ tăng, tăng độ hòa tan của các thành phần có trong dầu cám gạo [12]. Tuy nhiên khi chiết ở áp suất cao (350-450 bar), thì sự ảnh hưởng của áp suất chiết tới độ hòa tan của dầu trong dung môi $\mathrm{CO}_{2}$ là ít, vì thế khối lượng dầu cám thu được ở những áp suất này thay đổi không nhiều. Do vậy áp suất chiết xuất là 400 bar được lựa chọn.

Khảo sát sự ảnh hưởng của nhiệt độ chiết: tiến hành chiết dầu cám gạo với các thông số quy trình như sau: khối lượng mẫu cám $\mathrm{C} 2$ là $50 \mathrm{~g}$, nhiệt độ chiết $40-80{ }^{\circ} \mathrm{C}$, áp suất chiết 400 bar, tốc độ dòng $\mathrm{CO}_{2} 25 \mathrm{~g} /$ phút, thời gian chiết 120 phút. Kết quả như trong Bảng 4.

Bảng 4. Hiệu suất chiết dầu cám gạo và hàm lượng $\gamma$-oryzanol khi thay đổi nhiệt độ chiết

\begin{tabular}{|l|l|l|}
\hline $\begin{array}{l}\text { Nhiệt độ } \\
\left({ }^{\circ} \mathrm{C}\right)\end{array}$ & $\begin{array}{l}\text { Hiệu suất chiết } \\
\text { dâu cám gạo }(\%)\end{array}$ & $\begin{array}{l}\text { Hàm lượng } \\
\gamma \text {-oryzanol }(\%)\end{array}$ \\
\hline 40 & 15,50 & 0,31 \\
\hline 60 & 16,27 & 0,50 \\
\hline 80 & 10,52 & 0,44 \\
\hline
\end{tabular}

Kết quả cho thấy hiệu suất chiết dầu cám gạo khi chiết ở nhiệt độ $60^{\circ} \mathrm{C}$ cao nhất $(16,27 \%)$, thấp nhất ở nhiệt độ $80^{\circ} \mathrm{C}(10,52 \%)$. Về chất lượng dầu cám gạo ở nhiệt độ $60^{\circ} \mathrm{C}$ thu được hàm lượng $\gamma$-oryzanol $(0,5 \%)$ cũng cao nhất so với khi chiết xuất ở hai nhiệt độ còn lại.

Tốc độ khuếch tán $\mathrm{CO}_{2}$ vào dầu cám gạo và sự tăng áp suất hơi của dầu cám khi tăng nhiệt độ có tác động rất nhiều tới khả năng hòa tan thành phần dầu trong dung môi $\mathrm{CO}_{2}$ siêu tới hạn. Ở áp suất thấp, tỷ trọng $\mathrm{CO}_{2}$ sẽ giảm rất nhiều khi tăng nhiệt độ, làm giảm tốc độ khuếch tán của $\mathrm{CO}_{2}$ qua cám gạo. Tuy nhiên tỷ trọng $\mathrm{CO}_{2}$ ở điều kiện 
áp suất cao giảm không nhiều khi tăng nhiệt độ, hơn nữa tốc độ khuếch tán của $\mathrm{CO}_{2}$ cũng thay đổi ít. Khi giữ áp suất chiết cao (400 bar), tăng nhiệt độ từ $60^{\circ} \mathrm{C}$ lên $80^{\circ} \mathrm{C}$ thì tỷ trọng $\mathrm{CO}_{2}$ giảm [12], do đó độ tan của dầu cám gạo trong dung môi $\mathrm{CO}_{2}$ siêu tới hạn giảm và tốc độ khuếch tán của $\mathrm{CO}_{2}$ vào dầu cám gạo cũng giảm dẫn tới giảm hiệu suất chiết.

Khi chiết ở điều kiện áp suất 400 bar và nhiệt độ $60^{\circ} \mathrm{C}$ thì $\gamma$-oryzanol cũng cho thấy khả năng tan tốt hơn. Như vậy, qua khảo sát cho thấy điều kiện nhiệt độ và áp suất chiết xuất ảnh hưởng tới tỷ trọng $\mathrm{CO}_{2}$ và áp suất hơi của dầu dẫn tới sự thay đồi khả năng hòa tan của dầu cám gạo và $\gamma$-oryzanol trong dung môi $\mathrm{CO}_{2}$ siêu tới hạn, từ đó làm hiệu suất chiết xuất và hàm lượng $\gamma$-oryzanol trong dầu cám gạo ở các điều kiện khác nhau là khác nhau [12].

Khảo sát sự ảnh hưởng của tốc độ dòng $\mathrm{CO}_{2}$ : tiến hành chiết dầu cám gạo với các thông số quy trình như sau khối lượng mẫu cám $\mathrm{C} 2$ là $50 \mathrm{~g}$, nhiệt độ chiết $60^{\circ} \mathrm{C}$, áp suất chiết 400 bar, tốc độ dòng $\mathrm{CO}_{2} 20-30 \mathrm{~g} /$ phút, thời gian chiết 120 phút. Kết quả như trong Bảng 5 .

Bảng 5 . Hiệu suất chiết dầu cám gạo và hàm lượng $\gamma$-oryzanol khi thay đổi nhiệt độ chiết

\begin{tabular}{|l|l|l|}
\hline $\begin{array}{l}\text { Tốc độ dòng } \\
\mathrm{CO}_{2} \\
(\mathrm{~g} / \text { phút })\end{array}$ & $\begin{array}{l}\text { Hiệu suất } \\
\text { chiết dầu cám } \\
\text { gạo }(\%)\end{array}$ & $\begin{array}{l}\text { Hàm lượng } \gamma- \\
\text { oryzanol } \\
(\%)\end{array}$ \\
\hline 20 & 14,84 & 0,50 \\
\hline 25 & 16,27 & 0,50 \\
\hline 30 & 16,67 & 0,52 \\
\hline
\end{tabular}

Kết quả cho thấy khi tăng tốc độ dòng $\mathrm{CO}_{2}$ thì hiệu suất chiết dầu cám gạo tăng lên nhưng không nhiều, tốc độ dòng chiết $\mathrm{CO}_{2}$ là $30 \mathrm{~g} /$ phút cho hiệu suất cao nhất $(16,67 \%)$. Về hàm lượng $\gamma$-oryzanol trong dầu cám gạo thì ở tốc độ dòng $30 \mathrm{~g} /$ phút cũng cao hơn tốc độ dòng $20 \mathrm{~g} /$ phút và tốc độ dòng $25 \mathrm{~g} / \mathrm{phút}(0,52 \%$ so với $0,50 \%)$. Tuy nhiên sự khác biệt của hiệu suất chiết dầu cám gạo và hàm lượng $\gamma$-oryzanol ở ba tốc độ dòng khác nhau không nhiều. Nguyên nhân là do khi tăng tốc độ dòng $\mathrm{CO}_{2}$ thì tăng tỷ lệ số phân tử $\mathrm{CO}_{2}$ trên mồi đơn vị khối lượng của cám gạo, làm tăng sự tương tác giữa phân tử $\mathrm{CO}_{2}$ và cám gạo, do đó làm tăng khả năng hòa tan dầu cám trong dung môi. Mặt khác khi tăng tốc độ dòng $\mathrm{CO}_{2}$ cũng làm tăng sự chuyển khối, do vậy làm tăng lượng dầu cám gạo được hòa tan [12]. Vì vậy, trong quá trình chiết, để tiết kiệm chi phí $\mathrm{CO}_{2}$, chúng tôi lựa chọn tốc độ dòng $\mathrm{CO}_{2}$ là $20 \mathrm{~g} /$ phút.

So sánh với phương pháp chiết Soxhlet: tiến hành chiết xuất dầu cám gạo bằng phương pháp chiết Soxhlet với $n$-hexan. Dầu cám gạo được đánh giá hàm lượng $\gamma$-oryzanol. Kết quả nghiên cứu thể hiện như trong Bảng 6 .

\section{Bảng 6. Hiệu suất chiết dầu cám gạo và hàm lượng $\gamma$-oryzanol trong dầu cám gạo khi chiết bằng các phương pháp khác nhau}

\begin{tabular}{|l|l|l|}
\hline Phương pháp & $\begin{array}{l}\text { Hiệu suất chiết } \\
\text { dâu cám gạo } \\
(\%)\end{array}$ & $\begin{array}{l}\text { Hàm lượng } \\
\gamma \text {-oryzanol } \\
(\%)\end{array}$ \\
\hline $\begin{array}{l}\text { Chiết xuất } \\
\text { bằng dung } \\
\text { môi } \mathrm{CO}_{2} \text { siêu } \\
\text { tới hạn }\end{array}$ & 14,84 & 0,50 \\
\hline $\begin{array}{l}\text { Chiết } \\
\text { Soxhlet }\end{array}$ & 16,71 & 0,42 \\
\hline
\end{tabular}

Kết quả cho thấy hiệu suất chiết dầu cám gạo bằng bình chiết Soxhlet với $\mathrm{n}$-hexan $(16,71 \%)$ cao hơn khi chiết với dung môi $\mathrm{CO}_{2}$ siêu tới hạn $(14,84 \%)$ do một số acid béo trong dầu cám gạo có ái lực với $n$-hexan cao hơn so với dung môi $\mathrm{CO}_{2}$ siêu tới hạn [19], hiệu suất thu hồi dầu cám gạo của phương pháp sử dụng dung môi $\mathrm{CO}_{2}$ siêu tới hạn so với chiết Soxhlet cao, đạt 88,81\%. Tuy nhiên hàm lượng $\gamma$-oryzanol trong dầu cám gạo khi sử dụng dung môi $\mathrm{CO}_{2}$ siêu tới hạn $(0,5 \%)$ cao hơn khi chiết Soxhlet $(0,42 \%)$. Kết quả này cũng tương tự như trong công bố của Kuk và Dowd [19].

Như vậy, nghiên cứu đã chiết xuất được dầu cám gạo từ cám gạo bằng phương pháp sử dụng dùng dung môi siêu tới hạn, đây được coi là công nghệ xanh cho việc chiết xuất các chất tự nhiên có giá trị cao từ các loại thực vật có thành phần phức tạp, thu hút sự quan tâm rất nhiều từ các nhà khoa học trong lĩnh vực thực phẩm, dược phẩm và mỹ phẩm $[20,21]$. Dung môi $\mathrm{CO}_{2}$ siêu tới hạn là một dung môi lý tưởng cho việc chiết 
xuất các chất nhạy cảm với nhiệt và các nghiên cứu trước đã chỉ ra rằng nó là dung môi thích hợp cho việc chiết xuất các hợp chất thân dầu [22].

Trong nghiên cứu này, điều kiện chiết đã được lựa chọn như sau: áp suất 400 bar, nhiệt độ $60^{\circ} \mathrm{C}$, tốc độ dòng $\mathrm{CO}_{2} 20 \mathrm{~g} /$ phút, thời gian chiết xuất 120 phút; hiệu chất chiết dầu cám gạo và hàm lượng $\gamma$-oryzanol trong dầu cám gạo tương ứng là $14,84 \%$ và $0,50 \%$. So sánh với một số nghiên cứu trước, cho thấy kết quả của nhóm nghiên cứu về hiệu suất chiết và hàm lượng $\gamma$-oryzanol trong dầu cám gạo gần tương đương. Năm 2008, Chen và cộng sự [11] đã tiến hành chiết xuất dầu cám gạo bằng phương pháp dùng dung môi $\mathrm{CO}_{2}$ siêu tới hạn ở nhiệt độ $40^{\circ} \mathrm{C}$, áp suất 300 bar, tốc độ dòng $\mathrm{CO}_{2} 10 \mathrm{~g} / \mathrm{phút}$, sau 210 phút thu được hàm lượng dầu đạt $15,7 \%$, hàm lượng $\gamma$-oryzanol trong dầu cám gạo là $0,63 \%$. Một nghiên cứu khác của Kuk và Dowd năm 1998 [19] đã chiết xuất được dầu cám gạo với hiệu suất tối đa là $20,4 \%$ bằng dung môi $\mathrm{CO}_{2}$ siêu tới hạn ở áp suất 620 bar, nhiệt độ $100^{\circ} \mathrm{C}$, nghiên cứu cũng đã chỉ ra rằng nồng độ $\gamma$-oryzanol trong dầu cám gạo khi chiết xuất dùng dung môi $\mathrm{CO}_{2}$ siêu tới hạn cao hơn phương pháp chiết Soxhlet với n-hexan.

\section{Kết luận}

Nghiên cứu đã bước đầu xử lý được độ ổn định của cám gạo trong 8 tháng bằng phương pháp sấy tầng sôi và đã chiết xuất được dầu cám gạo sử dụng dung môi $\mathrm{CO}_{2}$ siêu tới hạn ở áp suất 400 bar, nhiệt độ $60^{\circ} \mathrm{C}$, tốc độ dòng $\mathrm{CO}_{2} 20 \mathrm{~g} /$ phút, thời gian chiết 120 phút, hiệu suất chiết xuất $14,84 \%$. Hàm lượng $\gamma$-oryzanol trong dầu cám gạo thu được đạt $0,50 \%$ cao hơn khi chiết xuất với dung môi n-hexan bằng phương pháp Soxhlet.

\section{Tài liệu tham khảo}

[1] A. A. Wani, P. Singh, M. A. Shah, U. S. Weisz, K. Gul, I. A. Wani, Rice Starch Diversity: Effects on Structural, Morphological, Thermal, and Physicochemical Properties A Review, Comprehensive Reviews in Food Science and Food Safety, Vol. 11, No. 5, 2012, pp. 417-436, https://doi.org/10.1111/j.15414337.2012.00193.x.

[2] K. Gul, B. Yousuf, A. K. Singh, P. Singh, A. A. Wani, Rice Bran: Nutritional Values and Its Emerging Potential for Development of Functional Food - A Review, Bioactive Carbohydrates and Dietary Fibre, Vol. 6, No. 1, 2015, pp. 24-30, https://doi.org/10.1016/j.bcdf.2015.06.002.

[3] G. Hua, S. Huang, S. Cao, Z. Ma, Effect of Enrichment with Hemicellulose from Rice Bran on Chemical and Functional Properties of Bread, Food Chemistry, Vol. 115, No. 3, 2009, pp. 839-842, https://doi.org/10.1016/j.foodchem.2008.12.092.

[4] T. S. Shin, J. S. Godber, Changes of Endogenous Antioxidants and Fatty Acid Composition in Irradiated Rice Bran during Storage, Journal of Agricultural Food Chemistry, Vol. 44, 1996, pp. 567-573, https://doi.org/10.1021/jf950386a.

[5] B. O. Juliano, P. A. Hicks, Rice Functional Properties and Rice Food Products, Food Reviews International, Vol. 12, No. 1, 1996, pp. 71-103, https://doi.org/10.1080/87559129609541068.

[6] M. Ghosh, Review on Recent Trends in Rice Bran Oil Processing, J Amer Oil Chem Soc, Vol. 84, 2007, pp. 315-324, https://doi.org/10.1007/s11746-007-1047-3.

[7] M. Sugano, E. Tsuji, Rice Bran Oil and Cholesterol Metabolism, Journal of Nutrition, Vol. 127, No. 3, 1997, pp. 521-524, https://doi.org/10.1093/jn/127.3.521S.

[8] G. S. Seetharamaiah, N. Chandrasekhara, Studies on Hypocholesterolemic Activity of Rice Bran Oil, Atherosclerosis, Vol. 78, No. 2-3, 1989, pp. 219-223, https://doi.org/10.1016/00219150(89)90226-8.

[9] J. K. Duve, P. J. White, Extraction and Identification of Antioxidants in Oats, Journal of American Oil Chemists Society, Vol. 68, No. 6, 1991, pp. 365-37, https://doi.org/10.1007/BF02663751.

[10] L. Xu, X. Zhan, Z. Zeng, R. Chen, H. Li, T. Xie, S. Wang, Recent Advances on Supercritical Fluid Extraction of Essential Oils, African Journal of Pharmacy and Pharmacology, Vol. 5, No. 9, 2011, pp. 1196-1211, https://doi.org/10.5897/AJPP11.228.

[11] C. R. Chen, C. H. Wang, L. Y. Wang, Z. H. Hong, S. H. Chen, W. J. Ho, C. M. J. Chang, Supercritical Carbon Dioxide Extraction and Deacidification of Rice Bran Oil, J. of Supercritical Fluids, Vol. 45, No. 3, 2008, pp. 322-331, https://doi.org/10.1016/j.supflu.2008.01.006. 
[12] K. Tomita, S. Machmudah, Wahyudiono, R. Fukuzato, H. Kanda, A. T. Quitain, M. Sasaki, M. Goto, Extraction of Rice Bran Oil by Supercritical Carbon Dioxide and Solubility Consideration, Separation and Purification Technology, Vol. 125, No. 7, 2014, pp. 319-325, http://dx.doi.org/10.1016/j.seppur.2014.02.008.

[13] F. Malekian, R. M. Rao, W. Prinyawiwatkul, W. E. Marshall, M. Windhauser, M. Ahmedna, Lipase and Lipoxygenase Activity, Functionality, and Nutrient Losses in Rice Bran During Storage, Bull. La. Agric. Exp. Stn. LSU Agric. Cent., Vol. 870, 2000, pp. 1-68.

[14] S. Akter, M. Ahiduzzaman, Effect of Storage Life of Rice Bran on the Quality of Oil, Journal of Food and Nutrition Sciences, Vol. 5, No. 1, 2017, pp. 11-15, https://doi.org/10.11648/j.jfns.20170501.12.

[15] H. R. Sharma, G. S. Chauhan, K. Agrawal, Physico-Chemical Characteristics of Rice Bran Processed by Dry Heating and Extrusion Cooking, International Journal of Food Properties, Vol. 7, No. 3, 2004, pp. 603-614, https://doi.org/10.1081/JFP-200033047.

[16] N. R. Lakkakula, M. Lima, T. Walker, Rice Bran Stabilization and Rice Bran Oil Extraction using Ohmic Heating, Bioresource Technology, Vol. 92,
No. 2, 2004, pp. 157-161, https://doi.org/10.1016/j.biortech.2003.08.010.

[17] D. Martin, J. S. Gober, G. Selhako, L. Verma, J. H. Wells, Optimizing Rice Bran Stabilization by Extrusion Cooking, Lousiana Agraculture, Vol. 30, 1993, pp. 13.

[18] R. N. Sayre, R. M. Saunders, R. V. Enochian, W. G. Shultz, E. C. Beagle, Review of Rice Bran Stabilization Systems with Emphasis on Extrusion Cooking, Cereal Food World, Vol. 7, 1982, pp. 317.

[19] M. S. Kuk, M. K. Dowd, Supercritical $\mathrm{CO}_{2}$ Extraction of Rice Bran, J. Am. Oil Chem. Soc, Vol. 75, 1998, pp. 623-628.

[20] Y. T. Chen, Y. H. Ling, An Overview of Supercritical Fluid Extraction in Chinese Herbal Medicine: from Preparation to Analysis, J. Food Drug Anal, Vol. 8, No. 4, 2000, pp. 235-247, https://doi.org/10.38212/2224-6614.2815.

[21] S. R. S. Ferreira, Z. L. Nikolov, L. K. Doraiswamy, M. A. A. Meireles, A. J. Petenatee, Supercritical Fluid Extraction of Black Pepper (Piper nigrun L.) Essential Oil, J. Supercrit. Fluids, Vol. 14, No. 3, 1999, pp. 235-245.

[22] A. Awasthi, R. K. Trivedi, A Review of Supercritical Carbon Dioxide Extraction of Natural Products, Chem. Eng. World, Vol. 32, 1997, pp. 65-71. 